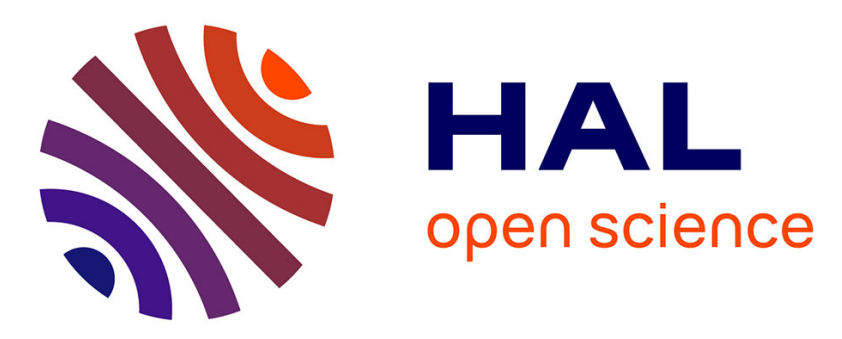

\title{
Prescribed burning in southern Europe: developing fire management in a dynamic landscape
}

\author{
Paulo M Fernandes, G Matt Davies, Davide Ascoli, Cristina Fernandez, \\ Francisco Moreira, Eric Rigolot, Cathelijne R Stoof, José Antonio Vega, \\ Domingo Molina
}

\section{To cite this version:}

Paulo M Fernandes, G Matt Davies, Davide Ascoli, Cristina Fernandez, Francisco Moreira, et al.. Prescribed burning in southern Europe: developing fire management in a dynamic landscape. Frontiers in Ecology and the Environment, 2013, 11 (1), pp.e4-e14. 10.1890/120298 . hal-02650706

\section{HAL Id: hal-02650706 https: / hal.inrae.fr/hal-02650706}

Submitted on 29 May 2020

HAL is a multi-disciplinary open access archive for the deposit and dissemination of scientific research documents, whether they are published or not. The documents may come from teaching and research institutions in France or abroad, or from public or private research centers.
L'archive ouverte pluridisciplinaire HAL, est destinée au dépôt et à la diffusion de documents scientifiques de niveau recherche, publiés ou non, émanant des établissements d'enseignement et de recherche français ou étrangers, des laboratoires publics ou privés. 


\title{
Prescribed burning in southern Europe: developing fire management in a dynamic landscape
}

\author{
Paulo M Fernandes ${ }^{1,2 *}$, G Matt Davies ${ }^{3}$, Davide Ascoli ${ }^{4}$, Cristina Fernández ${ }^{5}$, Francisco Moreira ${ }^{2}$, Eric Rigolot $^{6}$, \\ Cathelijne R Stoof ${ }^{7}$, José Antonio Vega ${ }^{5}$, and Domingo Molina ${ }^{8}$
}

Mediterranean landscapes are in a state of flux due to the impacts of changing land-use patterns and climate. Fuel-weather interactions determine that large, severe wildfires are increasingly common. Prescribed burning in southern Europe is therefore justified by the need to manage fire-prone vegetation types and maintain cultural landscapes that provide a range of ecosystem services. Prescribed fire has neutral or positive effects on soils and biodiversity, in contrast to wildfires, which can be extremely damaging. However, the limited extent of current applications are unlikely to reduce wildfire hazard or carbon emissions. Adoption of prescribed burning in the Mediterranean region has been slow, uneven, and inconsistent, and its development is constrained by cultural and socioeconomic factors as well as by specific factors related to demography, land use, and landscape structure. Sustainable fire management requires expansion of managers' ability to use prescribed burning, a varied response to unplanned fires, and modified regulation of burning associated with traditional agricultural land uses.

Front Ecol Environ 2013; 11 (Online Issue 1): e4-e14, doi:10.1890/120298

$\mathrm{S}_{\mathrm{M}}^{\mathrm{o}}$ uthern European landscapes are fire-prone due to the Mediterranean climate, the presence of flammable vegetation, and the rugged terrain (Pausas et al. 2008). The environmental and societal impacts of fire in the region have increased markedly during the 20th century.

\section{In a nutshell:}

- In southern Europe, prescribed burning is used to decrease wild fire risk and to manage habitats for grazing and wildlife, but it remains underused compared with other regions of the world

- The environmental implications of more frequent or larger prescribed fires, including impacts on wildfire incidence and carbon emissions, remain poorly understood

- Because of the strong policy-related and practical barriers to prescribed burning, fire management policies should be pragmatic and should include unplanned fires as complements to prescribed burning

- Given the highly dynamic nature of Mediterranean landscapes, an evidence-based, experimental, and adaptive approach to prescribed burning and fire management is recommended

${ }^{1}$ Centro de Investigação e de Tecnologias Agro-Ambientais e Biológicas, Universidade de Trás-os-Montes e Alto Douro, Vila Real, Portugal (pfern@utad.pt); ${ }^{2}$ Centro de Ecologia Aplicada Prof Baeta Neves, Instituto Superior de Agronomia, Universidade Técnica de Lisboa, Lisboa, Portugal; ${ }^{3}$ Solway Centre for Environment and Culture, University of Glasgow, Dumfries, Scotland; ${ }^{4}$ Dipartimento di Scienze Agrarie, Forestali e Alimentari, Università di Torino, Grugliasco, Italy; ${ }^{5}$ Centro de Investigación Forestal de Lourizan, Xunta de Galicia, Pontevedra, Spain; ${ }^{6}$ UR629 Ecologie des Forêts Méditerranéennes, INRA, Avignon, France; ${ }^{7}$ Department of Biological and Environmental Engineering, Cornell University, Ithaca, NY; ${ }^{8}$ Departament PVCF, Universitat de Lleida, Lleida, Spain

Pre-industrial fire regimes were generally associated with widespread agropastoral land use and low-severity burning in heterogeneous shrublands and open woodland landscapes (Seijo and Gray 2012). Pronounced changes leading to greater fire risk have since occurred as a result of socioeconomic and political factors that led to agricultural decline, abandonment, and mechanization; rural depopulation; large-scale afforestation; poor forest management; accumulation of biomass (fuel) in shrublands; land-use conflicts; and the expansion of urban areas (Birot 2009; Moreira et al. 2011; Seijo and Gray 2012). These processes present southern European countries with a unique fire management challenge in the context of a landscape still undergoing rapid change.

The severity of contemporary (post-1960s) fire regimes is also the result of climatic changes, including both generally hotter, drier weather and more frequent and extreme episodes of drought (Seidl et al. 2011), as well as modern fire suppression strategies that have further contributed to the increase in fuel (Piñol et al. 2007). An increase in the number and size of large fires (that account for most of the area burned) in the Mediterranean region suggests that fire regimes have shifted from fuel-limited to weather-driven (Pausas and Fernández-Muñoz 2011). However, fire management policies in southern Europe remain strongly biased toward fire suppression and largely disregard the structural (socioeconomic and land management) roots of the problem (Birot 2009).

Prescribed burning (PB) is the planned use of fire to achieve precise and clearly defined objectives. In Europe this can be distinguished from the more haphazard use of fire in traditional agriculture, for example in the manage- 
ment of grazed shrublands. Prescribed burning has been introduced in southern Europe primarily to control fire regimes by managing fuels, counteracting the disappearance of biomass-consuming practices and reducing the fire risks inherent in highly flammable forests and shrublands. Any change in fire regimes through increased use of PB has potential consequences for a range of ecosystem services, and it is critical that such issues be addressed. Here, we characterize PB in southern Europe and review three crucial issues of concern to land managers and society in general: (1) the effects of PB on soil and water resources, (2) its impact on biodiversity, and (3) the associated fire risk. A fourth concern, landscape management of carbon $(\mathrm{C})$ stocks and emissions, is an issue that cuts across each of these other categories.

\section{Prescribed burning in southern Europe: research and management}

Prescribed burning experiments in southern Europe were first conducted in the Mediterranean pine forests of Greece in the late 1960s (Liacos 1986). However, it was not until the late 1970s that efforts resumed, due to collaboration with researchers in the US and a growing interest in the study of fire ecology. Scientific output on $\mathrm{PB}$ in southern Europe has increased exponentially (Figure 1) since the first peer-reviewed paper was published in 1988. Initially, most research came from Spain, Portugal, and France, the output of international collaborative projects funded by the European Commission. This research sought to understand the effects of $\mathrm{PB}$ on ecosystem components (particularly soil and vegetation), as this was the primary management concern. A variety of interrelated issues concerning PB application technology and planning (eg fire behavior, fuel consumption, C emissions) were subsequently addressed. Because fire risk in the Mediterranean Basin is thought to be higher in pine forests and shrublands (Moreira et al. 2011), these broadly fire-adapted vegetation types have been the primary subjects of PB studies. Research on PB has led to a substantially improved understanding of the ecology and behavior of low-intensity fires. This had previously been neglected in Europe because of a strong focus on wildfire dynamics.

Montiel and Kraus (2010) describe in detail the genesis and development of PB management programs in Europe. After an experimental period in the late 1970s, PB was implemented in Portuguese and Spanish pine forests (early 1980s) and in French shrublands (late 1980s). Italy is currently undergoing an experimental PB phase (Ascoli and Bovio 2013). Decreasing the fire risk was the initial motivation for $\mathrm{PB}$, particularly to control fuel accumulation in pine stands tolerant of low-intensity fire and to create and maintain fuel breaks in shrublands (Figure 2; Table 1), but the use of PB has since expanded to include a wide array of other objectives, from range management to biodiversity conservation (Table 1). Currently, PB in the Mediterranean

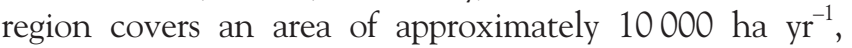
which is substantially smaller than that affected by traditional fire use (Panel 1); by way of comparison, this is only about $3 \%$ of the extent of wildfire in Portugal, Spain, and France (Ascoli and Bovio 2013). A compilation of southern European prescribed burns for various land-management goals is provided by Fernandes and Loureiro (2010):

- $\mathrm{PB}$ use is much more widespread in shrublands than in forests, but its application remains limited and local-toregional in scope. The spatial pattern of PB is either random or strategic (ie linear strips), and landscape-scale fuel treatment projects are uncommon. Prescribed burning plots are typically small, usually $<30$ ha, but can be as large as 200 ha. Patch mosaic burning is used to constrain fire spread within zones demarcated by the less-flammable conditions created by previously burned areas.

- International collaborations and interactions between fire researchers and fire managers and stakeholders were, and still are, instrumental in PB's adoption and 

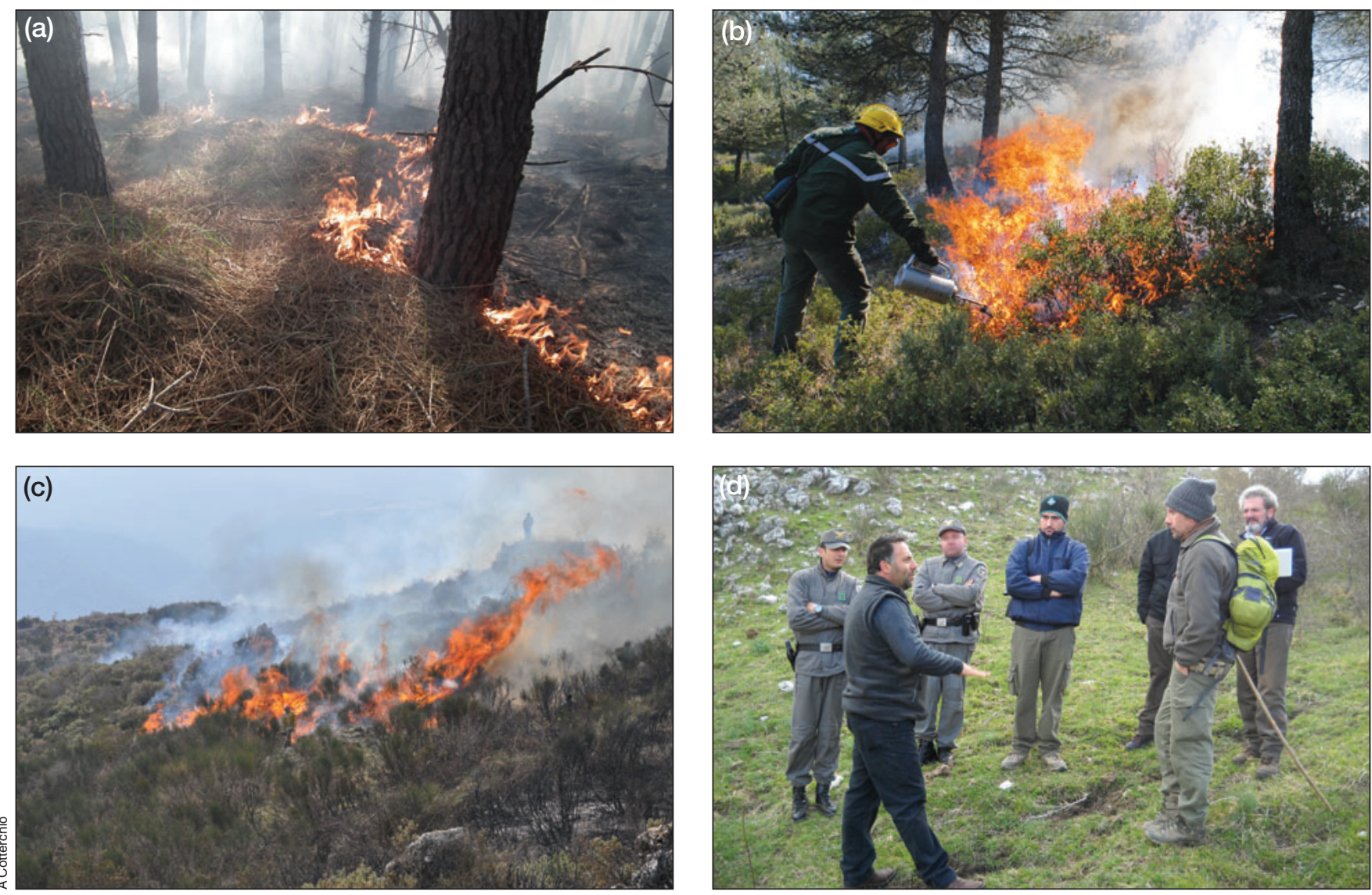

Figure 2. Prescribed burning in fire-adapted pines: (a) maritime pine (Pinus pinaster) in Portugal and (b) Aleppo pine (Pinus halepensis) in France. (c) Prescribed burning in Spartium-dominated shrubland in France. (d) Livestock shepherds discuss the use of prescribed fire with Forest Service officers and researchers in Italy's Cilento National Park.

expansion (Figure 2d). Prescribed burning can therefore be characterized as both research-led and adaptive.

- Prescribed burning programs have in some instances (eg Spain, France) replaced or restored pastoral burning practices through cooperation with local communities, thereby integrating traditional ecological knowledge into $\mathrm{PB}$ programs and reconciling range management with forest management (Panel 1).

A variety of factors constrain the expansion and consolidation of PB in southern Europe (Xanthopoulos et al.
2006), including risk-related concerns, a shortage of experienced professionals and organizations, the prevailing public perception of fire solely as a negative disturbance, and legislation that omits or prohibits the use of fire (eg in Greece). Additionally, the amount of land treatable by $\mathrm{PB}$ is restricted by the relatively high population density and the extent of the rural-urban interface (RUI), the predominance of private over public land, and scarce resources for forest management in general and fuel treatments in particular.

The fire-exclusion legacy of the 19th century German

\begin{tabular}{llll}
\hline \multicolumn{2}{l}{ Table 1. Established PB practices, by vegetation type, in southern Europe } & \\
\hline Broad vegetation type & Species & Countries & Burn objective \\
\hline Mediterranean pine forest & $\begin{array}{l}\text { Pinus canariensis, Pinus halepensis, } \\
\text { Pinus nigra, Pinus pinaster, } \\
\text { Pinus pinea }\end{array}$ & Portugal, Spain, France & $\begin{array}{l}\text { Hazard reduction; range or biodiversity } \\
\text { management as secondary objectives }\end{array}$ \\
\hline Mediterranean shrubland & $\begin{array}{l}\text { Variable, but usually dominated by } \\
\text { Cistus spp or Quercus coccifera }\end{array}$ & France, Portugal & $\begin{array}{l}\text { Hazard reduction; range and/or biodiversity } \\
\text { management }\end{array}$ \\
\hline Heathland & $\begin{array}{l}\text { Ulex spp, Erica spp, Calluna } \\
\text { vulgaris, Pterospartum tridentatum, } \\
\text { Cytisus spp, Genista spp }\end{array}$ & Portugal, Spain & Hazard reduction; range management \\
\hline $\begin{array}{l}\text { Mountain shrubland and } \\
\text { grassland }\end{array}$ & $\begin{array}{l}\text { Cytisus oromediterraneus, Cytisus } \\
\text { scoparius, Spartium junceum }\end{array}$ & France, Spain & $\begin{array}{l}\text { Range management; biodiversity management and } \\
\text { hazard reduction as secondary objectives }\end{array}$ \\
\hline Eucalypt plantations & Eucalyptus globulus & Portugal & Hazard reduction; post-harvesting slash disposal \\
\hline
\end{tabular}


Fire has long been used by pastoral communities in the French Pyrenees as a tool for rangeland improvement. In the late 19th century, rural mountain populations began to decline; at the same time, the French National Forest Service launched a large reforestation program in the Pyrenees. Traditional burning was seen as a threat to these new plantations and French forestry law (circa 1924) became increasingly repressive with regard to traditional fire use (Métailié 198I).

The emergence of PB in the Pyrenees (Figure 3) during the late 20th century has, however, contributed to a revival of traditional burning practices; as such, over the past 30 years, the Pyrenees have become a natural laboratory for restoring fire use. Local responses have been highly variable: there is a gradient over the Pyrenees, with intensive PB programs operating on the Mediterranean side, enduring traditional burning practiced in the Atlantic region, and varying combinations of the two in locations in

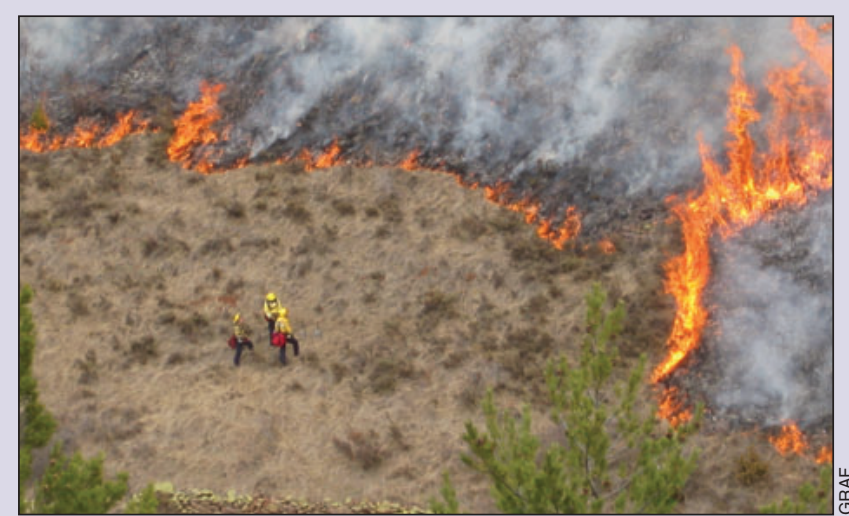

Figure 3. Prescribed burning of mountain grassland in the Pyrenees.

between. Local agencies involved in rural development and wildfire prevention in France's five Pyrenees départements have adapted to local contexts and adjusted their response based on the extent to which traditional fire-management practices have survived. Three examples illustrate this regional variability.

(I) Pyrénées-Orientales. Fire risk first became critical in the Pyrénées-Orientales after rural abandonment resulted in fuel buildup alongside progressive forest recolonization. Loss of traditional knowledge and poor burning practices were responsible for increased wildfire occurrence. By the mid-1980s the situation had become serious enough to encourage local authorities to launch one of the first French PB teams (Montiel and Kraus 2010). Their objectives were the strategic reduction of fire risk and improvement of grazing potential and range condition (Lambert and Parmain 1990). A rangeland extension service and the Forest Service, with support from civil protection crews, initially led the PB programs; today, firefighters are also included. Part of the challenge for the PB team was the provision of training to assist communities in restoring sustainable burning practices. Despite having one of the most active PB programs in France, only $0.6 \%$ of target areas in the Pyrénées-Orientales are treated annually (Montiel and Kraus 2010 ).

(2) Pyrénées-Atlantiques. This area is the most productive in terms of livestock in the Pyrenees because of its favorable bioclimate. Traditional burning for rangeland improvement remains widespread, with more than 10000 ha treated annually, representing almost $6 \%$ of the target areas. Nevertheless, restrictive regulations (eg a ban on burning during several months of the year, limited times for burning per day) led to poor practices, including agressive ignition patterns and much larger fires than necessary, resulting in frequent fire escapes and environmental damage. In 2000 , local stakeholders developed a participatory approach to improve dialogue, promote best practices, and establish local fire committees. Voluntary burning requests have since increased, while damage to the area's forestry has declined. However, the effect of burning on air quality is a pending issue.

(3) Hautes-Pyrénées. Although some traditional use of fire remains, it is much less common in this central region than in the PyrénéesAtlantiques. Until the 1990s, clandestine burning was frequent due to limited lawful opportunities, with unattended burning resulting in many fire escapes. New local fire regulations have since been introduced that recognize the need for burning by rangeland managers and organization of practitioners into local fire committees (Métailié et al. 1996). Each committee maps potential areas for pastoral burning, and these areas are further categorized into three levels of difficulty. While the two easiest levels can be performed by shepherds, the most difficult burns are carried out by a local PB team. The PB team also leads a working group on regulation adaptation. The new regulations are based on three principles: (I) acknowledgement of the potential agronomic and sociological advantages of burning, (2) that shepherds bear responsibility for their pastoral burning practices, and (3) substitution by specialized PB teams only when unavoidable.

The use of PB in the Pyrenees has facilitated the revival of best-practice traditional fire use within a regulated framework. The three examples above share common principles: rehabilitation of traditional pastoral fire use, a participatory approach, and support from fire professionals. They also share common tools: schools that teach good pasture-burning practices and adaptive regulation. Other regions in France are increasingly implementing these principles and tools. Integrating traditional knowledge within PB programs remains a key challenge (Lazaro and Montiel 20I0), but it is clear that both traditional fire use and formal PB practices are needed to maintain cultural landscapes in the mountainous areas of the Mediterranean.

forestry school is no longer relevant to fire management in the US (Donovan and Brown 2007) but still influences forestry professionals in Europe. Promising and successful $\mathrm{PB}$ programs have in the past been halted or substantially downsized because of changes in forest policy or a lack of institutional support (eg in the pine forests of the northwest Iberian Peninsula in the 1980s-1990s; Fernandes and Botelho 2004). Declines in the use of European forests for timber production and a greater emphasis on "sustainable" forest management are likely to discourage the adoption of PB in regions where the ecological role of fire in forest dynamics continues to be misunderstood or underrated (Diaci 2006).

Legal frameworks and professional accreditation schemes for PB currently exist only in France and Portugal (Montiel and Kraus 2010). Both burn objectives and the number 


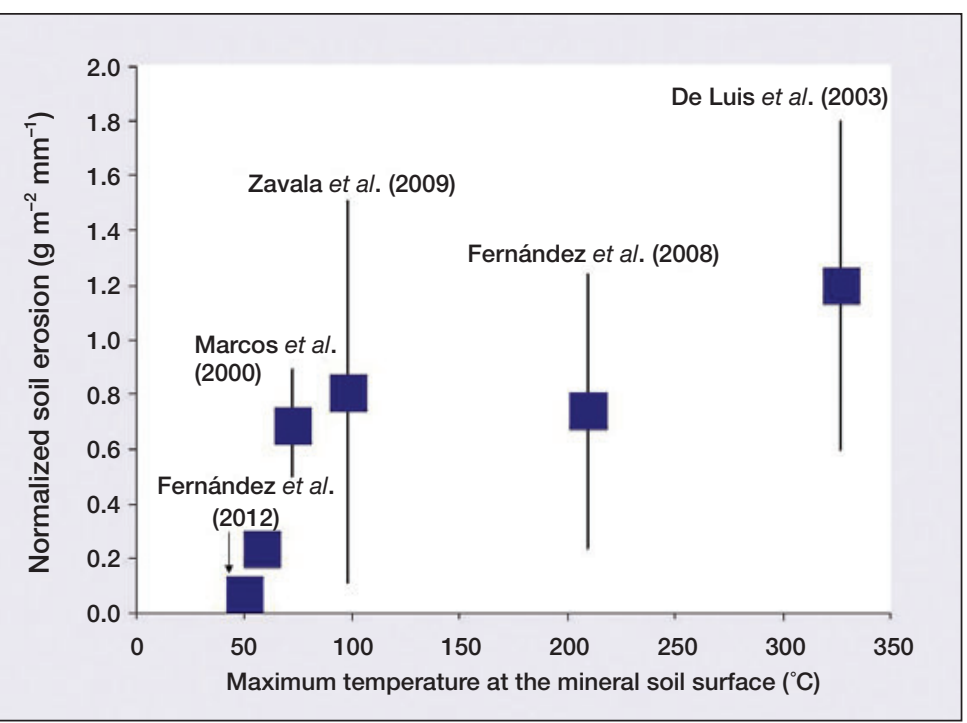

Figure 4. Normalized soil erosion $\left(\mathrm{g} \mathrm{m}^{-2} \mathrm{~mm}\right.$ rainfall $\left.{ }^{-1}\right)$, measured after $P B$ and rainfall simulations, versus maximum temperature $\left({ }^{\circ} \mathrm{C}\right)$ recorded at the mineral soil surface during burning.

and background of $\mathrm{PB}$ practitioners have rapidly diversified in France. Strong features of the French PB system include a dedicated network for exchanges of information between practitioners, knowledge transfer, and dialogue between stakeholders. However, the amount of treated land has remained largely the same because of increasing regulation, insufficient availability of supervisors, and the scarcity of days with suitable weather conditions, combined with insufficient preparedness to burn on those days. Prescribed burning is rarely a priority for fire- and land-management organizations, and therefore relies heavily on the motivation and effort of individuals within those agencies.

\section{Effects of PB on soil and water resources}

The increasing number of large, severe wildfires in the Mediterranean Basin has important implications for regional soil and water resources; for example, rates of soil loss (Pausas et al. 2008) and runoff and sediment yield (Mayor et al. 2007) have all increased, and the relative abundance of different forms of soil organic matter have been altered (Rovira et al. 2012). In addition, an increase in wildfires has been shown to have potentially negative effects on water quality (Smith et al. 2011). These processes suggest that increasing wildfire frequency or severity may interfere with the delivery of a range of ecosystem services, including the prevention of soil erosion, soil $\mathrm{C}$ sequestration, the provision of clean drinking water, and the preservation of aquatic biodiversity.

The effects of PB on soil properties are generally considered to be minor, but research results are often ambiguous. For instance, fire effects on soil microbiota are smaller than seasonal changes (Fonturbel et al. 2012), and soil chemical changes are either temporary or inconclusive (Úbeda et al. 2005; Outeiro et al. 2008). Likewise, soil hydrophobicity (the tendency of water to collect on the soil surface rather than infiltrating) has been found to both decrease (Zavala et al. 2009) and increase (Stoof et al. 2011a) following PB. Ferreira et al. (2008) reported repellency at PB sites to be more spatially heterogeneous than at wildfire sites, thereby favoring infiltration and mitigating runoff and erosion. This may be an explanation for the modest effects of $\mathrm{PB}$ on stream-water chemistry (Belillas and Rodà 1993) and erosion, despite observed increases in runoff (Marcos et al. 2000; Vega et al. 2005; Stoof et al. 2012). Erosion rates vary from non-significant changes (Zavala et al. 2009) to statistically significant increases, with post-fire erosion rates of between 2.3 and $842 \mathrm{~g}$ $\mathrm{m}^{-2}$ (Marcos et al. 2000; De Luis et al. 2003; Vega et al. 2005; Fernández et al. 2008; Fernández et al. 2012). While increases in erosion are greater after $\mathrm{PB}$ than following mechanical fuel treatments (Fernández et al. 2008; Fernández et al. 2012), they are usually lower than after wildfire (Soto and Diaz-Fierros 1998).

The limited effects of PB on soils and water are attributed to two key factors: limited soil heating (De Luis et al. 2003; Vega et al. 2005; Fernández et al. 2012) and the protective effect of the remaining surface cover (Vega et al. 2005; Fernández et al. 2012; Stoof et al. 2012). Increased temperatures seem to directly affect soil erosion (Figure 4), thereby underlining the importance of controlling soil heating during PB. Soil heating is influenced by the ignition pattern, the amount of moisture in the litter and soil, and the presence of rock fragments (eg Vega et al. 2005; Stoof et al. 2011b). Post-fire, litter should ideally cover $>70-80 \%$ of the ground surface to minimize erosion (Vega et al. 2005; Fernández et al. 2012), suggesting tradeoffs are necessary in managing fire and erosion risk.

With progressive soil degradation following repeated shrubland fires (Campo et al. 2006; González-Pelayo et al. 2010), the frequency of PB may be an important factor in terms of its impacts on soil and water. However, as with most other fuel treatments, little is known about the effects of repeated application of PB on soil degradation. The main question is, therefore, whether the cumulative effects of repeated $\mathrm{PB}$ are comparable to less frequent but more severe wildfire. Further work is required in this area. More information is also needed on whether targeting alternative burning seasons could decrease PB-induced erosion by allowing for more regeneration before the onset of convective rains, and how spatial patterns of $\mathrm{PB}$ can be designed to affect hydrological connectivity in a way that accommodates the treatment objectives while minimizing erosion rates (Ferreira et al. 2008).

\section{Prescribed burning and biodiversity}

Large-scale abandonment of agricultural lands over recent decades has had a profound effect on floral and faunal communities throughout the Mediterranean 
Basin. Dominant trends are characterized by the colonization of open agricultural habitats by shrubs and trees and the homogenization of existing shrubland habitats. Specific examples of biodiversity impacts include an increase of forests in Italy at the expense of open habitats with associated declines in typical Mediterranean fauna (Falcucci et al. 2007), and a decline in farmland bird diversity in the northwestern Mediterranean in relation to woodland and shrubland expansion (Sirami et al. 2008). We suggest a wider application of PB will substantially reduce the risk of large wildfires that would have negative impacts on biodiversity (Moreira and Russo 2007). Increased use of $P B$ will also maintain open areas and habitat heterogeneity in the absence of disturbance from traditional agriculture (Moreira and Russo 2007; Moreira et al. 2011).

In southern Europe, the use of PB for maintaining biodiversity has generally followed two scenarios: first, the preservation or restoration of valued shrubland habitats (eg heathlands dominated by common heather [Calluna vulgaris] and high-elevation Mediterranean shrublands) by reintroducing fire where cessation of grazing and/or burning has resulted in tree encroachment (eg Bartolomé et al. 2005), and the re-establishment of longer fire-return intervals in areas where poorly managed grazing and frequent pastoral fires have caused habitat degradation (Ascoli et al. 2013); and second, to improve habitat quality for species of conservation value (eg maintaining rabbit populations as a food source for vultures, lynx, and eagles; Moreno and Villafuerte 1995). Prescribed burning has been recommended as an effective means of creating open habitats that support species of conservation concern on abandoned farmlands (eg Brotons et al. 2008), and is also viewed as a tool for increasing structural and species diversity in formerly exploited forests (eg chestnut coppice woodlands) that are now abandoned and in transition to alternative ecosystem states dominated by seminatural ecological processes (eg Moretti et al. 2008).

There is little evidence that the use of PB to improve grazing quality in mountain pastures has had much effect on plant species richness and composition (eg Rigolot et al. 2002); in contrast, the effects on wildlife diversity have been varied. For example, negative impacts were observed for Orsini's viper (Vipera ursinii; Lyet et al. 2009) while little effect has been recorded on the survival rates of wood mice (Apodemus sylvaticus; Monimeau et al. 2002). On the other hand, Pons et al. (2003) found that populations of rare grassland birds increased following PB application. In forested areas, most studies show a negligible effect of $\mathrm{PB}$ on vegetation and wildlife diversity (eg Moreira et al. 2003). The small size and low intensity of burns in forests might be one of the reasons for the relatively small impact of PB in such areas.

Although the primary objectives of individual PB may vary (eg fuel reduction versus habitat creation for a particular species), decisions about where and how to burn must always be ecologically justifiable. This is a consider- able challenge in the Mediterranean Basin, where dynamic interactions between ongoing changes in landuse, climate, and natural and anthropogenic disturbances mean many ecological systems are not in equilibrium with the prevailing disturbance regimes (Pausas et al. 2008). Thus, for example, the cessation of grazing and traditional burning in some mountain shrublands means that current ecological structures are a relic of past disturbance regimes. Planning PB specifically for biodiversity objectives therefore requires an understanding of the impact of PB regimes as compared with the effects of single burns and implementation of long-term monitoring programs of intentionally burned areas. The effects of historical wildfire regimes on key species and communities can provide useful information (eg Trabaud and Galtié 1996) but (pre)historical ranges of fire regimes with which species and habitats evolved cannot be identified in southern Europe (Pausas et al. 2008). As an alternative, flexible PB regimes should be implemented as part of nature conservation programs by evaluating key species and habitat tolerances to different fire regimes, so that PB use can be kept within tolerable limits. This issue is particularly important given the uncertainty about the effects of PB on disturbance-dependent protected habitats (Halada et al. 2011) and the potential spread of invasive species (Maringer et al. 2012).

The implications for biodiversity management of larger scale PB application must also be considered. Benefits might arise from increased landscape heterogeneity (Moreira et al. 2001), but further research is needed. The possible role of $\mathrm{PB}$ in maintaining populations of threatened open-habitat species in the context of field "closure" by secondary vegetation succession has been highlighted by several authors (eg Moreira and Russo 2007; Brotons et al. 2008), although specific guidelines on burn size are scarce. Finally, the effects of PB on long-term successional processes in abandoned areas, including the potential for alternative developmental trajectories and stable states, still remain to be addressed.

\section{Risk-reduction effectiveness of PB}

The effectiveness of $\mathrm{PB}$ in reducing fire risk can be gauged by various indicators and at different spatial scales. Successful fire containment or fire behavior/severity mitigation in $\mathrm{PB}$ areas has been documented in case studies of wildfire in shrublands and pine forests in southern Europe (Fernandes and Botelho 2003). Persistence of the $\mathrm{PB}$ effect is dependent on the temporal dynamics of fuel accumulation and structure (eg decreases in shrub height and fuel loading of $62 \%$ and $44 \%$ from untreated to 3-year-old [after PB] heathland, respectively; these effects corresponded to a $78 \%$ decrease in fire intensity observed under comparable weather conditions; Vega et al. 2010). Experimental evidence from pine stands indicates lower surface-fire intensity for at least 10 years following $\mathrm{PB}$, and presumably for a longer period, at least 


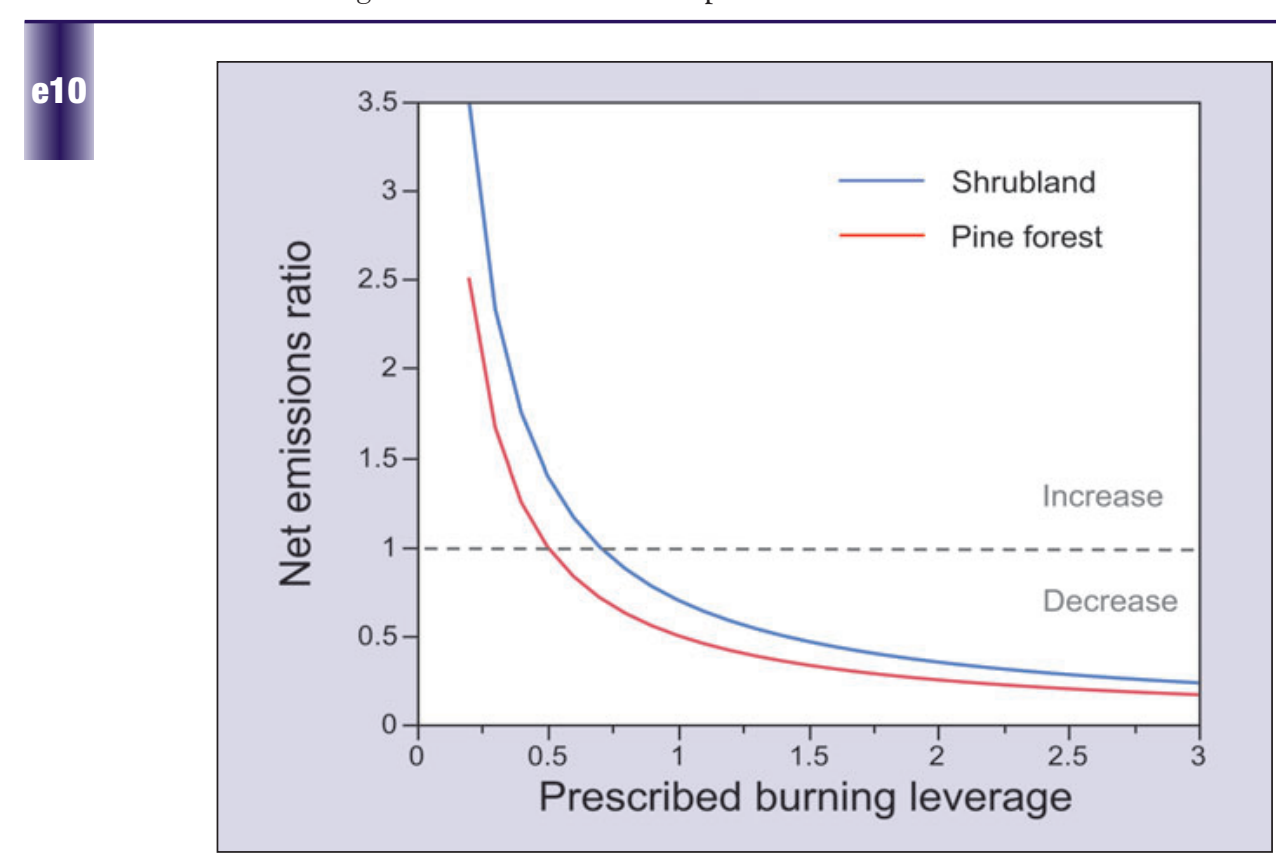

Figure 5. The effect of $\mathrm{PB}$ on $\mathrm{C}$ emissions according to the conceptual model of Bradstock et al. (2012). Variation is a function of PB leverage and the PB-towildfire ratio of fuel consumption, which is assumed to be 0.7 for shrubland (Fernandes et al. 2000) and 0.5 for pine forest (Narayan et al. 2007). Prescribed burning mitigates $\mathrm{C}$ emissions when the net emissions ratio is $<1$.

until the pre-treatment fuel structure has returned (Fernandes 2009), but suggests a shorter-lived effect in the mitigation of crown fires developing under severe weather conditions (Fernandes et al. 2004). Prescribed burning is therefore thought to be less effective in more productive environments, especially if extreme weather conditions become more frequent as a result of climate change.

Local-scale evidence- or modeling-based analyses of PB effectiveness are insufficient to assess its ability to modify larger scale regional fire regimes. Because of the limited use of $\mathrm{PB}$ in southern Europe, its effects on fire regimes are not quantifiable from empirical data; its effectiveness can, however, be expressed according to its "leverage" the decrease in wildfire area per unit area of $\mathrm{PB}$ - with a leverage value of $>1$ implying that $\mathrm{PB}$ decreases the total area burned. Substantial variation in PB leverage is theoretically possible as a function of wildfire extent, $\mathrm{PB}$ treatment effort, and the spatial patterns of treatment (Price 2012). Leverage is $\sim 0.25$ in Australian eucalypt forests and zero in southern California chaparral (Price et al. 2012), but it can be as high as 1.8 in Portuguese shrubland (Vilén and Fernandes 2011), possibly reflecting the combination of high fire incidence, extreme landscape fragmentation, and less severe fire weather in that region. Fire size variability and maximum fire size both decrease in more fire-frequent landscapes in Portugal (Fernandes 2010), indicating that the fuel mosaics created by pastoral burning can offer guidance for defining future spatial patterns of PB. Inferences from wildfire suggest that about $5 \%$ of the forest landscape could be a reasonable target for annual PB treatment (Vilén and Fernandes 2011). Fire modeling should be used to optimize PB treatment rate and location in the landscape and to assess the effectiveness of alternative fire-treatment strategies (eg random versus strategic burning, linear versus patch burning).

Prescribed burning offers risk-reduction benefits other than just decreased wildfire extent. For example, wildfire severity is reduced in areas that have recently been treated with $\mathrm{PB}$ and forest resilience is enhanced where use of PB prevents standreplacing fires.

\section{Prescribed burning and C management}

Some scientists have suggested that PB can be used as a tool to reduce $\mathrm{C}$ emissions (Narayan et al. 2007; Vilén and Fernandes 2011). The potential of $P B$ to mitigate $C$ emissions from the burning of aboveground biomass is directly related to its leverage value and varies with the amount of fuel consumed as compared with the amount of fuel consumed by a wildfire (Bradstock et al. 2012). Prescribed burning will decrease overall pyrogenic emissions in southern Europe if leverage $>0.5$ (pine forest) or $>0.7$ (shrubland; Figure 5). Additionally, high post-fire tree survival in burned open forests consisting of large, mature trees preserves $\mathrm{C}$ stocks in living tree biomass, but the $\mathrm{C}$ balance will still be influenced by PB leverage.

The approach illustrated in Figure 5 does not consider soil C stocks, which are quite high even in the Mediterranean region. Soil C storage may decrease in PB areas and increase in response to wildfires (Johnson and Curtis 2001) because of differences in charcoal production and post-fire litter fall. However, large and severe wildfires occur when soils are dry, which increases the likelihood of soil C oxidation. Regular low-severity PB (ie low fuel consumption, shorter residence times, and reduced temperature penetration belowground) protects against such losses and contributes to increased soil C over the long term through the sequential addition of highly stable "black" C (Adams 2013). A substantial amount of work is still needed to quantify the effects of $\mathrm{PB}$ on the $\mathrm{C}$ cycle and to model variations in the magnitude of different $\mathrm{C}$ pools in response to changes in landscape vegetation composition and fire frequency.

\section{Future perspectives and challenges}

Existing constraints are likely to preclude substantial increases in PB application in southern Europe for the foreseeable future. The current consensus among fire researchers and land managers on the need for more balanced fire management has yet to make an impression on 
policy makers and the general public (Birot 2009). Effective communication and promotion, education, and demonstration projects are therefore needed to raise awareness regarding the ecological role of fire and the benefits of PB. Nonetheless, expansion of PB under the political and socioeconomic frameworks that currently exist in southern Europe may be possible through the establishment or improvement of national standards for training, technical certification, and burn operations. Improved spatial and temporal planning is also required, implying a need for greater reliance on decision-support and reporting tools. The resulting increase in effectiveness of $\mathrm{PB}$, either perceived or real, combined with the operational consideration of C-related issues, is likely to increase the willingness of stakeholders to accept expanded PB programs.

Fire management should be focused on establishing a more sustainable fire regime, one that is characterized by less severe fires but not necessarily by reduced fire extent. However, prescribed burning is not the only option for achieving this goal. Alternative fire-management practices, such as pastoral burning, could contribute decisively to sound land management (Panel 1), but such management approaches are often met with resistance and/or indifference from policy makers and local communities. Landscapes that are undergoing rapid shifts in ecological state due to the cessation of traditional practices are especially challenging in this respect, as are sites where the maintenance of biodiversity values are incompatible with fire occurrence (eg due to the presence of fire-sensitive species).

Ecosystem services also benefit from distinct responses to unplanned fire events. Fire suppression should be conditional on the form of land use and burn severity (or fire weather), such that unplanned fires are monitored rather than extinguished if within "prescription" parameters. Social constraints (even at more remote or marginal locations) and the current capacity of firefighting organizations impose limits on unplanned fire management in southern Europe. However, under a scenario that combines climate change and decreased resources for management, pragmatism recommends a trade-off, whereby fire-management zoning defines where unplanned fire is allowed and where fuel treatments (including $\mathrm{PB}$ ) are given high priority (Fernandes 2013). Prioritization should be based on the ecological and economic value of the assets and ecosystem functions targeted for protection. Scaling up current $\mathrm{PB}$ practices to larger fires would contribute to increased acceptability of and ability to manage unplanned fires. This requires a better understanding of the links between $\mathrm{PB}$ and wildfire and a representative range of important ecosystem functions.

Five distinct challenges can be considered regarding the future of PB in southern Europe, relating to: the RUI, commercial forestry, mountain rangelands, forest reserves requiring protection from fire, and abandoned farmland (Table 2). Paradoxically, unless managers and researchers are better able to communicate its advantages to policy makers and other stakeholders, PB is likely to remain underdeveloped where fuel-hazard reduction is most needed. The implementation potential of PB at the RUI is currently restricted by social acceptance (eg concerns regarding smoke, risk of fire expansion) and by operational complexity. In commercial forests, even if other

\section{Table 2. The potential role of PB in fire and landscape management in southern Europe}

\begin{tabular}{|c|c|c|}
\hline Situation & Objective & Approach \\
\hline RUI & Protection of communities and assets from fire & PB used in fuel-break maintenance \\
\hline Production forests & Forest protection from fire & $\begin{array}{l}\text { PB used in shrubland and fuel breaks to isolate forests; } \\
\text { in forests adapted to low-intensity fire to reduce surface fuels; } \\
\text { and to manage post-harvest residues } \\
\text { Spatial and temporal planning is critical, including integration } \\
\text { with silviculture operations and schedules }\end{array}$ \\
\hline Mountain rangelands & $\begin{array}{l}\text { Grazing, with biodiversity as a byproduct; } \\
\text { management of cultural landscapes; fire severity } \\
\text { mitigation }\end{array}$ & $\begin{array}{l}\text { Patch mosaic of PB and traditional pastoral burning } \\
\text { Accommodation of unplanned fires }\end{array}$ \\
\hline Forest reserves & $\begin{array}{l}\text { Restoration of ecological processes (re-wilding); } \\
\text { provision of diverse ecosystem functions (eg C } \\
\text { storage, biodiversity, recreation) }\end{array}$ & $\begin{array}{l}\text { Variable and adaptive response to fire } \\
\text { PB to provide a diversity of fire regimes, from fire exclusion in } \\
\text { areas undergoing succession and in fire-sensitive vegetation } \\
\text { types, to low-intensity frequent fire in Mediterranean } \\
\text { coniferous forest } \\
\text { Management and use of naturally-ignited fires when "in } \\
\text { prescription" (ie occurring within a predetermined range of } \\
\text { conditions likely to produce beneficial results) }\end{array}$ \\
\hline Abandoned farmland & $\begin{array}{l}\text { Restoration of disturbance-dependent habitats and } \\
\text { species; improving habitat quality for "open land" } \\
\text { farmland species }\end{array}$ & $\begin{array}{l}\text { Variable and adaptive response to fire, depending on } \\
\text { habitat/species requirements } \\
\text { Management and use of naturally ignited fires when "in } \\
\text { prescription" }\end{array}$ \\
\hline
\end{tabular}


limiting factors are overcome, the cost-to-benefit ratio might be sufficiently high to hinder the adoption of PB. In the remaining three situations, the use of fire is justified to maintain cultural landscapes, to protect fire-sensitive habitats from wildfire, or to foster re-wilding; landuse and rural development policies will play an important role in these situations.

The implementation of PB for reasons other than firerisk management can be seen as a continuum of complexity, starting with the application of PB for exclusively utilitarian purposes, focused on a single resource (eg improving vegetation for grazing). However, as simple as this objective may seem, managing rangelands requires more than just rejuvenating pastures through burning. More knowledge is needed of the $\mathrm{PB}$ regimes that enhance forage quality and quantity in the long term. This might partly be achieved by integrating traditional ecological knowledge into $\mathrm{PB}$ programs. Likewise, knowledge gaps concerning the biology and ecology of species and habitats may limit the effectiveness of burning plans intended for nature conservation. This is particularly the case where the maintenance of a fire-dependent habitat of conservation value prevents ecological succession towards an alternative, but potentially valuable ecosystem state.

Using PB at a given location involves identifying tradeoffs between ecosystem services, because no single fire regime will be optimal (or even beneficial) for all services. The priority should be to ensure that landscapes are able to perform a range of ecosystem functions, so that even if one function is a particular priority, other services should always be considered during the development of PB plans. This is especially important in fire-prone landscapes, where large, severe wildfires have the potential to undermine the provisioning of valued services. It is also important given that "natural" fire regimes are unknown due to the frequency of human-induced ignitions and the long history and complex dynamics of land management which continue to drive ecosystems across the Mediterranean. A much more thorough understanding of the effects of variation in fire regimes on ecosystem functions is therefore necessary in these ecosystems; this would require dynamic, landscape-scale analysis and planning tools that assimilate information such as soil characteristics, climate/weather patterns, fuel and vegetation succession models, and human population density, to facilitate the accurate forecasting of fire danger. Providing the knowledge base to develop such tools should be a priority for researchers.

\section{口 Conclusions}

Research on PB and its use in southern Europe are at a relatively early stage and are somewhat less developed than in other regions of the world. There are still considerable institutional and cultural challenges preventing its widespread adoption in the Mediterranean region. Decisions about the future use of $\mathrm{PB}$ are currently being taken in the context of (1) substantial vegetation changes, most noticeably related to land-use abandonment leading to shrubland and forest expansion, and (2) altered weather patterns as a result of climate change. The considerable interactions likely to occur between these two factors will lead to novel conditions for PB, in which current models of fire behavior and ecological dynamics may be of limited applicability. There can be no certainty that current practices will continue to guarantee safe and effective burning operations for the full range of ecosystem functions that benefit from fire management. A robust, evidence-based, and adaptive approach to $\mathrm{PB}$ is therefore needed. We suggest that the future of $\mathrm{PB}$ should follow three principles:

- Operations and outcomes must be continually monitored, and operational practice should learn from traditional ecological knowledge where available.

- Experimentation should be encouraged and documented, including ecologically justified "risk taking" by managers. Such experimentation needs to be facilitated by policy makers.

- Regulations should be subject to regular review and should be flexible, so as to facilitate regional development of regulations governing the use of $\mathrm{PB}$. Such rules should set out broad principles and requirements for planning and applying PB and should clarify such issues as potential liabilities.

\section{Acknowledgements}

We thank J Russell-Smith and J Cardoso Pereira as well as support by the European Union FEDER/COMPETE Operational Competitiveness Program and FCT (Portuguese Foundation for Science and Technology) under the projects FCOMP-01-0124-FEDER-022696 and PTDC/AGRCFL/099420/2008.

\section{References}

Adams, MA. 2013. Mega-fires, tipping points and ecosystem services: managing forests and woodlands in an uncertain future. Forest Ecol Manage 294: 250-61.

Ascoli D and Bovio G. 2013. Prescribed burning in Italy: a review of issues, advances and challenges. iForest 6: 79-89.

Ascoli D, Lonati M, Marzano R, et al. 2013. Prescribed burning and browsing to control tree encroachment in southern European heathlands. Forest Ecol Manage 289: 69-77.

Bartolomé J, Plaixats J, Fanlo R, and Boada M. 2005. Conservation of isolated heathlands in the Mediterranean region: effects of land-use changes in the Montseny Biosphere Reserve (Spain). Biol Conserv 122: 81-88.

Belillas CM and Rodà F. 1993. The effects of fire on water quality, dissolved nutrient losses and the export of particulate matter from dry heathland catchments. J Hydrol 150: 1-17.

Birot Y (Ed). 2009. Living with wildfires: what science can tell us. Joensuu, Finland: European Forest Institute. Discussion Paper 15.

Bradstock RA, Boer M, Cary GJ, et al. 2012. Modelling the potential for prescribed burning to mitigate carbon emissions from 
wildfires in fire-prone forests of Australia. Int $J$ Wildland Fire 21: 629-39.

Brotons L, Herrando S, and Pons P. 2008. Wildfires and the expansion of threatened farmland birds: the ortolan bunting Emberiza hortulana in Mediterranean landscapes. J Appl Ecol 45: 1059-66.

Campo J, Andreu V, Gimeno-García E, et al. 2006. Occurrence of soil erosion after repeated experimental fires in a Mediterranean environment. Geomorphology 82: 376-87.

De Luis M, González-Hidalgo JC, and Raventós J. 2003. Effects of fire and torrential rainfall on erosion in a Mediterranean gorse community. Land Degrad Dev 14: 203-13.

Diaci J. 2006. Nature-based silviculture in Slovenia: origins, development and future trends. In: Diaci J (Ed). Nature-based forestry in Central Europe: alternatives to industrial forestry and strict preservation. Ljubljana, Slovenia: University of Ljubljana.

Donovan GH and Brown TC. 2007. Be careful what you wish for: the legacy of Smokey Bear. Front Ecol Environ 5: 73-79.

Falcucci A, Maiorano L, and Boitani L. 2007. Changes in landuse/land-cover patterns in Italy and their implications for biodiversity conservation. Landscape Ecol 22: 617-31.

Fernandes PM and Botelho HS. 2003. A review of prescribed burning effectiveness in fire hazard reduction. Int J Wildland Fire 12: 117-28.

Fernandes PM and Botelho HS. 2004. Analysis of the prescribed burning practice in the pine forest of northwestern Portugal. $J$ Environ Manag 70: 15-26.

Fernandes PM and Loureiro C. 2010. Handbook to plan and use prescribed burning in Europe. Vila Real, Portugal: UTAD. FIRE PARADOX (FP-018505EC) Integrated Project.

Fernandes PM, Catchpole WR, and Rego FC. 2000. Shrubland fire behaviour modelling with microplot data. Can J Forest Res 30: 889-99.

Fernandes PM, Loureiro C, and Botelho HS. 2004. Fire behaviour and severity in a maritime pine stand under differing fuel conditions. Ann For Sci 61: 537-44.

Fernandes PM. 2009. Examining fuel treatment longevity through experimental and simulated surface fire behaviour: a maritime pine case study. Can J Forest Res 39: 2529-35.

Fernandes PM. 2010. Creating fire smart forests and landscapes. For Mediterr 31: 417-22.

Fernandes PM. 2013. Fire-smart management of forest landscapes in the Mediterranean basin under global change. Landscape Urban Plan 110: 175-82.

Fernández C, Vega JA, Fontúrbel T, et al. 2008. Immediate effects of prescribed burning, chopping and clearing on runoff, infiltration and erosion in a shrubland area in Galicia (NW Spain). Land Degrad Dev 19: 502-15.

Fernández C, Vega JA, and Fontúrbel T. 2012. The effects of fuel reduction treatments on runoff, infiltration and erosion in two shrubland areas in the north of Spain. J Environ Manage 105: 96-102.

Ferreira AJD, Coelho COA, Ritsema CJ, et al. 2008. Soil and water degradation processes in burned areas: lessons learned from a nested approach. CATENA 74: 273-85.

Fontúrbel MT, Barreiro A, Vega JA, et al. 2012. Effects of an experimental fire and post-fire stabilization treatments on soil microbial communities. Geoderma 191: 51-60.

González-Pelayo O, Andreu V, Gimeno-García E, et al. 2010. Rainfall influence on plot-scale runoff and soil loss from repeated burning in a Mediterranean-shrub ecosystem, Valencia, Spain. Geomorphology 118: 444-52.

Halada L, Evans D, Romão C, and Petersen J-E. 2011. Which habitats of European importance depend on agricultural practices? Biodivers Conserv 20: 2365-78.

Johnson DW and Curtis PS. 2001. Effects of forest management on soil $\mathrm{C}$ and $\mathrm{N}$ storage: meta analysis. For Ecol Manage 140: 227-38.
Lambert B and Parmain V. 1990. Les brûlages dirigés dans les Pyrénées-Orientales. De la régénération des pâturages d'altitude à la protection des forêts. Rev For Franc 62: 140-55.

Lazaro A and Montiel C. 2010. Overview of prescribed burning policies and practices in Europe and other countries. In: Silva JS, Rego F, Rigolot E, and Fernandes P (Eds). Towards integrated fire management - outcomes of the European project Fire Paradox. Joensuu, Finland: European Forest Institute. EFI Research Report 23.

Liacos L. 1986. Le pâturage et le feu prescrit, des outils efficaces dans l'aménagement des forêts méditerranéennes du groupe pin d'Alep. Options Méditerranennes: Série Etudes 1986-I: 179-99.

Lyet A, Cheylan M, Prodon R, and Besnard A. 2009. Prescribed fire and conservation of a threatened mountain grassland specialist: a capture-recapture study on the Orsini's viper in the French Alps. Anim Conserv 12: 238-48.

Marcos E, Tarrega R, and Luis-Calabuig E. 2000. Comparative analysis of runoff and sediment yield with a rainfall simulator after experimental fire. Arid Soil Res Rehab 14: 293-307.

Maringer J, Wohlgemuth T, Neff C, et al. 2012. Post-fire spread of alien plant species in a mixed broad-leaved forest of the Insubric region. Flora 207: 19-29.

Mayor AG, Bautista S, Llovet J, and Bellot J. 2007. Post-fire hydrological and erosional responses of a Mediterranean landscape: seven years of catchment-scale dynamics. CATENA 71: 68-75.

Métailié JP. 1981. Le feu pastoral dans les Pyrénées centrales (Barousse, Oueil, Larboust). Toulouse, France: Editions du CNRS.

Métailié JP, Buffière D, Faerber J, and le Caro P. 1996. Local committees of prescribed burning and rangeland management in the central French Pyrenees. In: West NE (Ed). Rangelands in a sustainable biosphere. Proceedings of the 5th International Rangeland Congress; 23-28 Jul 1995; Salt Lake City, UT. Denver, CO: Society for Range Management.

Monimeau L, Mouillot D, Fons R, et al. 2002. Impact of prescribed burning on the survival rates of the wood mouse (Apodemus sylvaticus). Acta Oecol 23: 51-58.

Montiel C and Kraus D (Eds). 2010. Best practices of fire use - prescribed burning and suppression fire programmes in selected case-study regions in Europe. Joensuu, Finland: European Forest Institute. EFI Research Report 24.

Moreira F, Ferreira PG, Rego FC, and Bunting S. 2001. Landscape changes and breeding bird assemblages in northwestern Portugal: the role of fire. Landscape Ecol 16: 175-87.

Moreira F, Delgado A, Ferreira S, et al. 2003. Effects of prescribed fire on vegetation structure and breeding birds in young Pinus pinaster stands of northern Portugal. Forest Ecol Manage 184: 225-37.

Moreira F and Russo D. 2007. Modelling the impact of agricultural abandonment and wildfires on vertebrate diversity in Mediterranean Europe. Landscape Ecol 22: 1461-76.

Moreira F, Viedma O, Arianoutsou M, et al. 2011. Landscape wildfire interactions in southern Europe: implications for landscape management. J Environ Manage 92: 2389-2402.

Moreno S and Villafuerte R. 1995. Traditional management of scrubland for the conservation of rabbits Oryctolagus cuniculus and their predators in Doñana National Park, Spain. Biol Conserv 73: 81-85.

Moretti M, Staehli, and Gillet F. 2008. Determinants for the conservation of a vulnerable fire-dependent species at its marginal range. Plant Ecol 199: 89-98.

Narayan C, Fernandes PM, Van Brusselen J, and Schuck A. 2007. Potential for $\mathrm{CO}_{2}$ emissions mitigation through prescribed burning in the context of the Kyoto Protocol. Forest Ecol Manage 251: 164-73.

Outeiro L, Asperó F, and Úbeda X. 2008. Geostatistical methods to study spatial variability of soil cations after a prescribed fire and rainfall. CATENA 74: 310-20.

Pausas JG and Fernández-Muñoz S. 2012. Fire regime changes in 
the Western Mediterranean Basin: from fuel-limited to drought-driven fire regime. Climatic Change 110: 215-26.

Pausas JG, Llovet J, Rodrigo A, and Vallejo R. 2008. Are wildfires a disaster in the Mediterranean basin? - A review. Int J Wildland Fire 17: 713-23.

Piñol J, Castellnou M, and Beven KJ. 2007. Conditioning uncertainty in ecological models: assessing the impact of fire management strategies. Ecol Model 207: 34-44.

Pons P, Henry P-Y, Gargallo G, et al. 2003. Local survival after fire in Mediterranean shrublands: combining capture-recapture data over several bird species. Popul Ecol 45: 187-96.

Price OF, Bradstock RA, Keeley JE, and Syphard AD. 2012. The impact of antecedent fire area on burned area in southern California coastal ecosystems. J Environ Manage 113: 301-07.

Price OF. 2012. The drivers of effectiveness of prescribed fire treatment. Forest Sci 58: 606-17.

Rigolot E, Lambert B, Pons P, and Prodon R. 2002. Management of a mountain rangeland combining periodic prescribed burnings with grazing: impacts on vegetation. In: Trabaud L and Prodon R (Eds). Fire and biological processes. Leiden, the Netherlands: Backhuys.

Rovira P, Romanyà J, and Duguy B. 2012. Long-term effects of wildfires on the biochemical quality of soil organic matter: a study on Mediterranean shrublands. Geoderma 179-180: 9-19.

Seidl R, Schelhaas M-J, and Lexer MJ. 2011. Unravelling the drivers of intensifying forest disturbance regimes in Europe. Glob Change Biol 17: 2842-52.

Seijo F and Gray R. 2012. Pre-industrial anthropogenic fire regimes in transition: the case of Spain and its implications for fire governance in Mediterranean type biomes. Hum Ecol Rev 19: $58-69$.

Sirami C, Brotons L, Burfield I, et al. 2008. Is land abandonment having an impact on biodiversity? A meta-analytical approach to bird distribution changes in the north-western Mediterranean. Biol Conserv 141: 450-59.

Smith HG, Sheridan GJ, Lane PNJ, et al. 2011. Wildfire effects on water quality in forest catchments: a review with implications for water supply. J Hydrol 396: 170-92.
Soto B and Diaz-Fierros F. 1998. Runoff and soil erosion from areas of burnt scrub: comparison of experimental results with those predicted by the WEPP model. CATENA 31: 257-70.

Stoof CR, De Kort A, Bishop TFA, et al. 2011a. How rock fragments and moisture affect soil temperatures during fire. Soil Sci Soc Am J 75: 1133-43.

Stoof CR, Moore D, Ritsema CJ, and Dekker LW. 2011b. Natural and fire-induced soil water repellency in a Portuguese shrubland. Soil Sci Soc Am J 75: 2283-95.

Stoof CR, Vervoort RW, Iwema J, et al. 2012. Hydrological response of a small catchment burned by experimental fire. Hydrol Earth Syst Sc 16: 267-85.

Trabaud L and Galtié J. 1996. Effects of fire frequency on plant communities and landscape pattern in the Massif des Aspres (southern France). Landscape Ecol 11: 215-24.

Úbeda X, Lorca M, Outeiro LR, et al. 2005. Effects of prescribed fire on soil quality in Mediterranean grassland (Prades Mountains, north-east Spain). Int J Wildland Fire 14: 379-84.

Vega JA, Fernández C, and Fontúrbel T. 2005. Throughfall, runoff and soil erosion after prescribed burning in gorse shrubland in Galicia (NW Spain). Land Degrad Dev 16: 37-51.

Vega JA, Fontúrbel MT, Ruiz AD, et al. 2010. Selvicultura preventiva de incendios forestales en formaciones de matorral del noroeste de España: análisis comparativa de la eficacia de los tratamientos y de los efectos edáficos producidos. Lourizán, Spain: CIF Lourizán.

Vilén T and Fernandes PM. 2011. Forest fires in Mediterranean countries: $\mathrm{CO}_{2}$ emissions and mitigation possibilities through prescribed burning. Environ Manage 48: 558-67.

Xanthopoulos G, Caballero D, Galante M, et al. 2006. Forest fuels management in Europe. In: Andrews PL and Butler BW (Eds). Fuels management - how to measure success: conference proceedings. 28-30 March 2006; Portland, OR. Fort Collins, CO: USDA Forest Service, Rocky Mountain Research Station. Proceedings RMRS-P-41.

Zavala LM, Jordán A, Gil J, et al. 2009. Intact ash and charred litter reduces susceptibility to rain splash erosion post-wildfire. Earth Surf Proc Land 34: 1522-32. 